\title{
Analysis of Shoreline Shift using Satellite Imagery near Makassar City
}

\author{
Rian Amukti ${ }^{1}$, Arif Seno Adji ${ }^{1}$, Syamsuri Ruslan ${ }^{2}$ \\ ${ }^{I}$ Department Center for Deep-Sea Research, Indonesian Institute of Sciences, Ambon 97233, Indonesia \\ ${ }^{2}$ Department of Fisheries and Marine Science, Universitas Muslim Indonesia, South Sulawesi 90231, Indonesia.
}

* Corresponding author : rian.amukti87@gmail.com

Tel.:+62 911322676 ; fax: +62 911322700

Received: June 5, 2020; Accepted: July 15, 2020

DOI : $10.25299 /$ jgeet.2020.5.3.5111

\begin{abstract}
Shoreline shift have occurred in the Coastal region of Makassar City in recent years due to abrasion and accretion. Spatial temporal feature extraction of the Makassar City Region has been carried out using remote sensing techniques withRadiometri, Geometric Corrections and Composite Imagein the Landsat image dataset in 2009 and 2019. This study aims to analyze shoreline shift near Makassar City with remote sensing technology using Landsat imagery data, based on multi-temporal data with visual and digital analysis techniques between 2009 and 2019 . This research contributes to local and central government as baseline data (data base) in making decisions for handling coastal areas. The results showed that the length of the Makassar City coastline without including the coastline length of the islands separated from land in a row that is equal to $37.79 \mathrm{~km}$ in 2009. While in 2019 there was a significant change that is $49.82 \mathrm{~km}$. This shows the addition of a coastline of $12.03 \mathrm{~km}$ in the span of 10 years. These changes are mainly caused by anthropogenic factors, namely the construction of the pier / port and the reclamation and hydrooceanographic factors, namely waves, currents and tides.
\end{abstract}

Keywords: Makassar, Abrasion, Accretion, Shoreline

\section{Introduction}

Makassar is the capital of the province of South Sulawesi, which is located in the southern part of Sulawesi Island, formerly called Ujung Pandang, located between 119 $24^{\prime} 17^{\prime} 38^{\prime \prime}$ East Longitude and $5^{\circ} 8^{\prime} 6^{\prime} 19^{\prime \prime}$ South Latitude bordering the North with Maros Regency, East Maros Regency, south of Gowa Regency and west of the Makassar Strait.

Makassar City is the capital of South Sulawesi Province and is the fourth largest city in Indonesia which has an area of $175.79 \mathrm{~km} 2$ with a length of $52.8 \mathrm{~km}$ consisting of coastline coastline along $36.1 \mathrm{Km}$, as well as the coastline of islands and gusung along $16.7 \mathrm{~km}$. Makassar City has a population of 1,339,374 inhabitants, so this city has become a Metropolitan city. Administratively, Makassar City consists of 14 districts and 143 villages.

The purpose of this study is to examine in depth the pattern of shoreline shift in the coastal area of Makassar City using remote sensing techniques with Radiometri, Geometric Corrections and Composite Image in the Landsat image dataset in 2009 and 2019

Knowledge of the changes in the shape of the coastline is very important for coastal area monitoring and is aimed at effective management of coastal areas. One appropriate technique used for monitoring this coastal area is remote sensing. This technology can be used as an inventory and monitoring of natural resources that are increasingly dynamic. With different geographical conditions for each island in Indonesia, monitoring can be done with the availability of real time, fast, multi-temporal, multi-spectral, multi-spatial, and sustainable data

The use of landsat imagery for shoreline determination is often used, for example by using the segmentation method with the AGSO and BILKO formula approaches, so that an optimal coastline is obtained (Agus et al. 2015). The use of google earth imagery in shoreline change analysis can also be done (Suwandana 2019). Shoreline changes can also be analyzed using Landsat data for 10 years using the digitization and overlay methods such as the Bengkulu beach case (Syukhriani, Nofridiansyah, and Sulistyo 2017). The accuracy of coastline geometry can also be analyzed using water indices on various land covers (Wicaksono and Wicaksono 2019). The coastline is also affected by the presence of sediments entering the river delta, by using remote sensing it can be calculated on the changes in the coastline (Fan et al. 2017)

According to Tejakusuma (2011) in Kulmawapa, et al., (2017). The coastal region is a very dynamic region. The interaction of human activities and natural activities will put pressure on the changing coastal environment. Over time, the pressure on the coastal environment will continue to increase, one of which is the problem of shoreline change.

The coastline is a boundary line between land and sea water. Each beach has a coastline with an irregular position, it can change because of natural and human factors. Factors from nature include sedimentation, coastal erosion and tides while factors from humans such as coastal excavation, reclamation, shore protection and regulation of river flow patterns .In a simple process the change in coastline is caused by wind and water that moves from a place continuously. Baseline coastline changes include abrasion and accretion (sedimentation) which can occur naturally due to natural and human factors. Sediment can be transported so far that it changes the position of the coastline. Sediment transport along the coastline is a major cause of shoreline changes. Changes in the coastline basically include abrasion and accretion (sedimentation) which can occur due to natural and human factors. Sediment can be transported so far that it changes the position of the coastline (Angkotasan, Nurjaya, and Natih 2012).

Changes in the coastline caused by abrasion or erosion occur due to ocean currents and sea waves that continuously hit 
the shoreline and the existence of a relatively flat beach, while the accretion process at the beach is caused by a buildup of sediment from the land and deposited on the coast, especially through the estuary river. Sediments originating from the mainland, and entering the river flow and being taken to the sea through estuaries, will also cause changes in the shape of the coastline. The mass of incoming sediment that is constantly accompanied by mud causes an increase in land area or siltation in the estuary and coastal sections. Accumulation of mud that settles and is trapped by mangrove vegetation over many years will cause land emergence (Fan et al. 2017).

Human efforts to utilize coastal areas are often not based on a good understanding of coastal behavior. As a result, many problems have arisen, one of which is abrasion and sedimentation of the coastline. Based on the above background, a research is needed to find out the changes in the coastline in Makassar City by utilizing technology that is easy, fast, and accurate, namely through monitoring the landsat imagery with remote sensing applications. Information on shoreline changes is very important in various coastal studies, for example; coastal area management plans, disaster mitigation, abrasion-accretion studies.

\section{Research Methods}

This research will be carried out in the city of Makassar precisely on the coast of Makassar City (Fig1). This location was chosen based on the following considerations:

(1) There is a change in coastline pattern in the coastal area of Makassar City.

(2) To examine in more detail the pattern of changes in coastline in the coastal area of Makassar City.

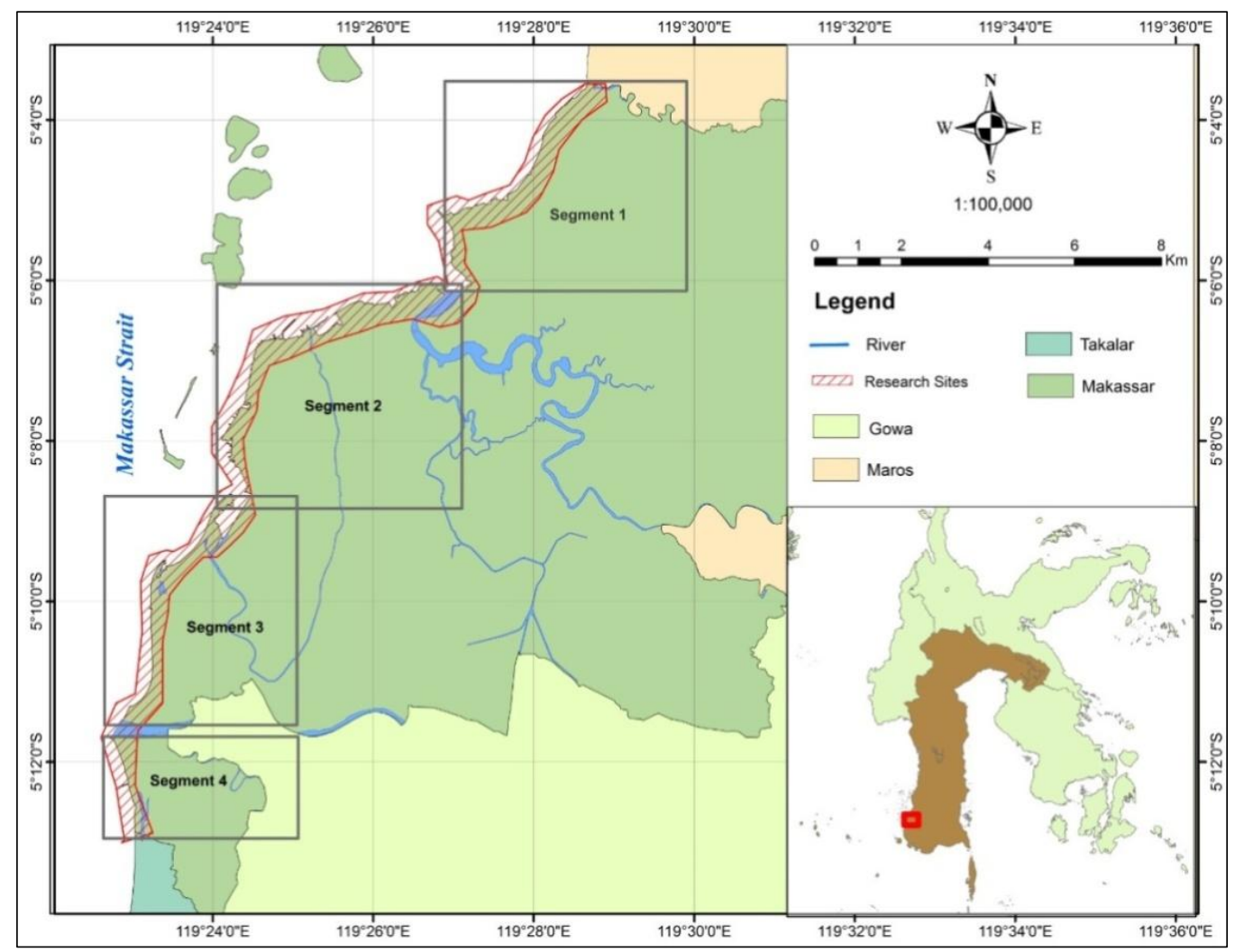

Fig. 1. Map of research location.

The procedures performed in this study are as follows: 1. Stage of Obtaining Image

The initial stage in carrying out the image is to download Landsat image data from the official USGS website (U.S Geological Survey).

2. Import data

Import Landsat 7 and 8 ETM + imagery data to be used. Landsat image data that is still in TIF format is converted to raster file format and vector format for analysis in ER Mapper Software.

\section{Layer stacking}

This process combines several different bands / channels to form the desired appearance. It is known that Landsat 8 consists of 11 bands, each of which has its own uses, while Landsat 7 consists of 6 bands. And to display a standard display of Landsat imagery, a band / channel merging process called stacking or composite is needed.

\section{Radiometric and Geometric Corrections}

Radiometric Correction is a process to improve the visual quality of an image, in terms of correcting pixel values that do not correspond to the reflectance value or the actual spectral radiance of the object. Meanwhile, geometric corrections contain geo-referenced data, both position (latitude and longitude coordinate system) and other information. 5. Subset

The cropping process is carried out so that the data analysis will focus on the object and area to be studied, as well as minimize the files used and speed up the processes in the ER Mapper when compared to processing a full scene.

6. Composite Image

Composite band process can be carried out for the classification process. The selection of the band to be used must be adjusted for the purpose of classification. The choice of band combination for observation of shoreline changes using composite color 543 for Landsat $7 \mathrm{ETM}+$ and Composite color 564 for Landsat 8 OLI. It is suitable for Land/Water distinction. 7. Image Sharpening

Image sharpening is done to further facilitate visual interpretation and understanding of an image. The advantage of digital data is that it allows us to manipulate the pixel values of 
an image, even though the image has been corrected for radiometric, atmospheric, and sensor characteristics before image data is distributed to users, but the appearance of the image is still less than optimal for visual interpretation. Image sharpening techniques are used in the context of image enhancement, increasing the gray scale change in pixel brightness values in terms of photographic print quality for interpretation in processing without returning to interactive digital analysis. The first step in the subjective process of digital classification.

8. Digitizing the Coastline

After multi-temporal corrected image, the next step is the on screen digitization process. Digitization is intended to change the format of raster data to vector data format. The object being digitized is the coastline. The entire digitization process uses image analysis facilities on ArcGIS software that can display raster and vector data at once.

9. Overlay

After the digitization phase is completed, the next process is to overlay the four coastlines above. After that an analysis of coastline changes in 2009 and 2019 was conducted.

10. Map Layout

The final process of image interpretation is to make the final output in the form of maps of changes in coastline, both in the form of softcopy and hardcopy (print out). The steps in the map layout are to select the view then select the layout view. Then set the map shape with the desired attributes according to the correct map making rules. After everything is finished save the data that has finished layout by selecting file> export map> JPEG> OK

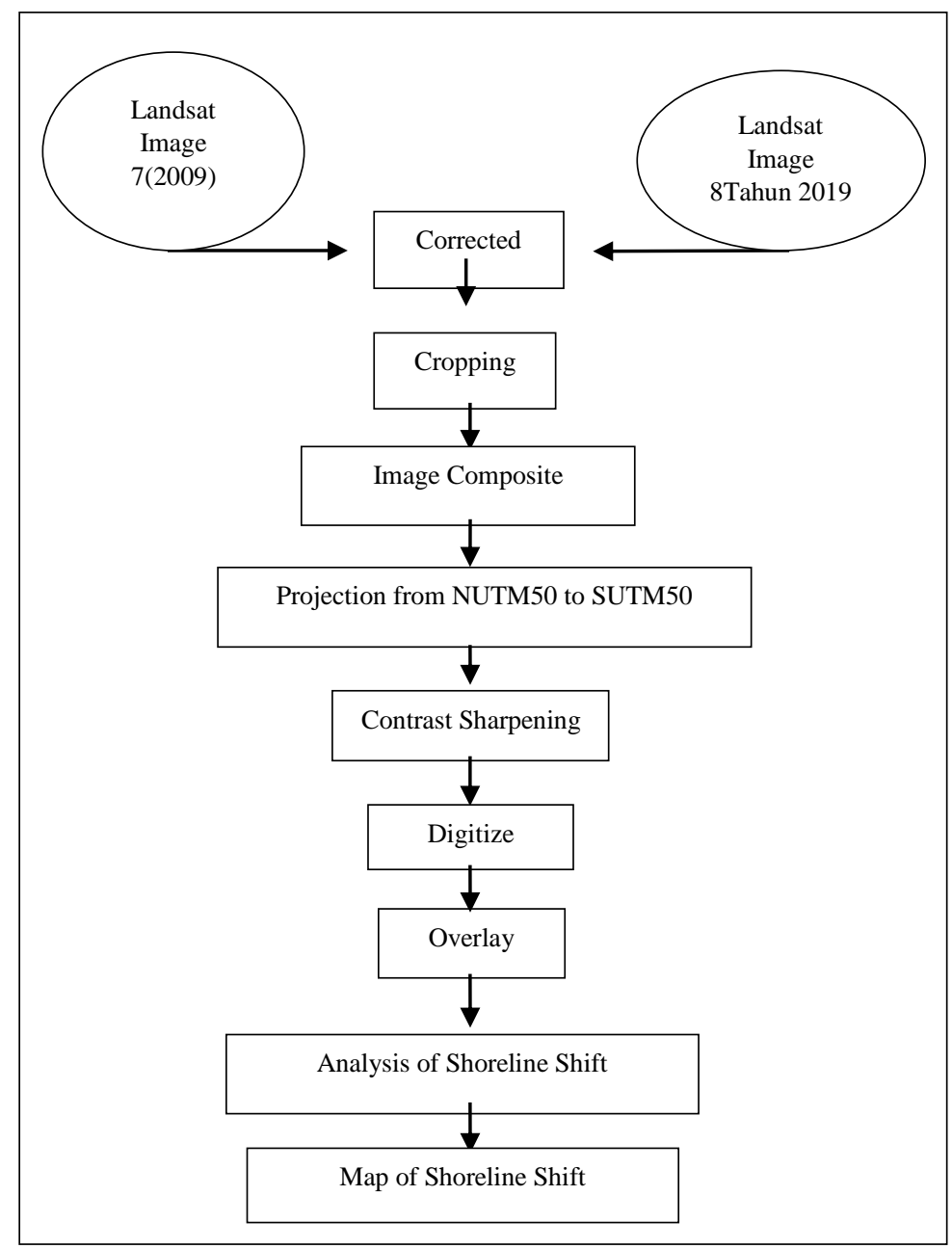

Fig 2. Flow Chart Analysis of Shoreline Shiftnear Makassar City

\section{Results and Discussion}

\section{Results}

The results of the coastline overlay in the Landsat imagery in 2009 and 2019 experienced significant coastline changes and showed abrasion and accretion. The change in the coastline was done by comparing the results of the 2009 coastline digitization and 2019. The 2009 coastline was used as the initial coastline to find out the coastline changes that have occurred over the past 10 years.

The results of overlays from Landsat image data in 2009 and 2019 can be seen that in all locations of research on the coast of Makassar City experiencing changes in the coastline due to abrasion and accretion. In general, along the coastline of Makassar City, it has been shown that in the last 10 years there has been a change in the coastline. This This consistent with the previoues research of Shorline changes detection using image satelite analyse near Gianyar (Aryastana, Eryani, and Candrayana 2015), the coast experiences abrasion, if the current coastline of the year is more landward than the previous coastline and vice versa for accreted beaches.

Mapping shoreline changes is done with the aim to clarify the shape of shoreline changes that have occurred on the coast of Makassar City over the past 10 years. Mapping shoreline changes is presented in Fig 3. 


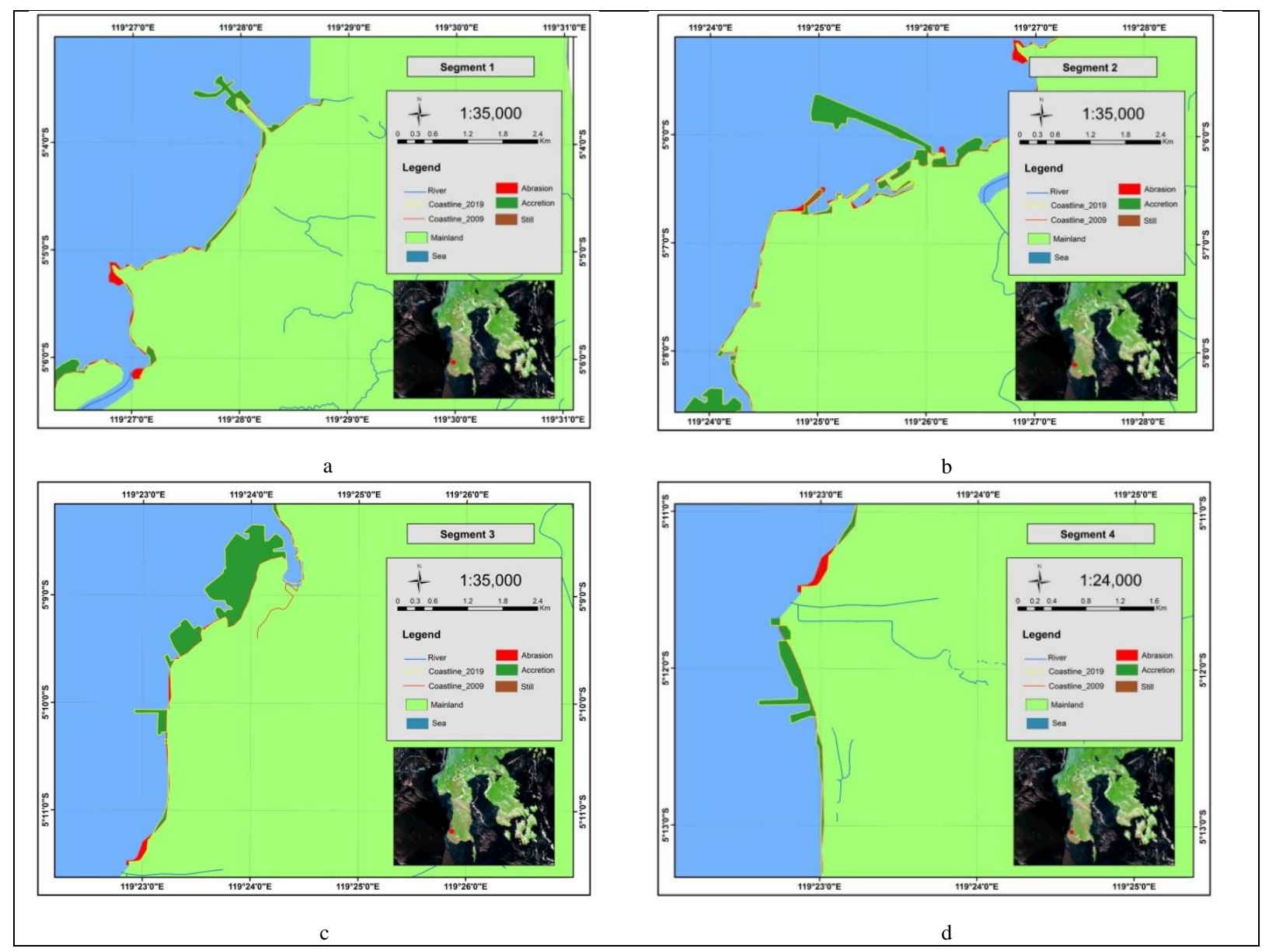

Fig 3. Mapping coastline changes in the coast of Makassar City (a) segment 1; (b) segment 2; (c) segment 3; (d) segment 4.

The results of the interpretation of Landsat image data in 2009, showed that the coastal area of Makassar City was still lacking of community settlements, the lack of land use change as tourist attractions, ports / docks, and the construction of coastal protective structures around the coast were still lacking.

The length of the coastline of Makassar City in 2009 was $10.14 \mathrm{~km}$ in segment 1 which included Biringkanaya District and Tamalanrea District. Segment 2 covers TalloDistrict, Ujung Tanah District, Wajo District and Ujung Pandang District having a coastline length of $17.48 \mathrm{~km} .7 .08 \mathrm{~km}$. In segment 3 which includes Tamalate District. Segment 4 covers Tamalate District which has a coastline length of $3.09 \mathrm{~km}$.

Unlike the case in 2019 , the increasing number of community settlements around the coast and the increasing use of land use change such as the making of docks / ports and the construction of coastal protective structures. The existence of communities that make settlements so that human factors can influence the occurrence of shoreline changes from the felling of trees which can cause erosion and littering. This can be one of the factors that influence changes in coastline in the form of abrasion and accretion along the coast of Makassar City over the past 10 years. The length of the coastline of Makassar City in 2019 is around $12.15 \mathrm{~km}$ in segment 1 . Segments 2 and 3 have a coastline length of $32.59 \mathrm{~km}$. While segment 4 has a coastline of $5.08 \mathrm{~km}$.

Accretion that occurred for 10 years (2009-2019) allegedly caused by coastal protective structures such as breakwater, because of the addition of land to make a breakwater. The existence of pier / port construction and reclamation. The coastal topography condition of the Makassar City area is sloping, so that the materials around the residential area will be carried to the sea by the current when it rains and the existence of Watersheds such as the Jeneberang River, Tallo River and
Pampang River which is a place for spreading sediment particles around the coast.

Table 1. The shape of shoreline changes in Makassar City in each segment in $2009-2019$. We use $\left(\mathrm{m}^{2}\right)$ because when done in the form of spatial calculations, only one permanent caused in the area did not change from 2009-20019 (fixed)

\begin{tabular}{clrrr}
\hline \multirow{2}{*}{ Segment } & Sub-district & Abra-sion & Accre-tion & $\begin{array}{c}\text { Perma- } \\
\text { nent }\end{array}$ \\
\cline { 3 - 5 } & - Biringkanaya & $11.580,14$ & & \\
\hline 1 & - Tamalanrea & $\mathrm{m}^{2}$ & & \\
2 & - Tallo & $105.233,53$ & & $28.738,48$ \\
& - Ujung Tanah & $\mathrm{m}^{2}$ & & $\mathrm{~m}^{2}$ \\
& - Wajo & $20.950,48$ & $209.090,08 \mathrm{~m}^{2}$ & $\mathrm{~m}^{2}$ \\
& - Ujung & $45.250,39$ & $72.183,47 \mathrm{~m}^{2}$ & \\
3 & Pandang & $\mathrm{m}^{2}$ & $59.053,53 \mathrm{~m}^{2}$ & \\
4 & - Tamalate & $20.034,79$ & $10.213,8 \mathrm{~m}^{2}$ & \\
& - Tamalate & $\mathrm{m}^{2}$ & $26.492,2 \mathrm{~m}^{2}$ & \\
& & $22.615,44$ & $1.369 .692,6 \mathrm{~m}^{2}$ & \\
& & $\mathrm{~m}^{2}$ & $201.070,21 \mathrm{~m}^{2}$ & \\
& & $74.836,05$ & & \\
& & $\mathrm{~m}^{2}$ & & \\
& & $18.543,62$ & & \\
\hline
\end{tabular}

The results of overlays conducted on Landsat 7 in 2009 and Landsat 8 in 2019 produced several crossing shorelines. These results are then sorted, then grouped into changes that are abrasion or changes are accretion. After identifying the location of abrasion and beach accretion by overlapping the longest coastline with the most recent year coastline. The addition of land in 2009-2019 amounted to 2,695,326.84 m2 with an area of each namely: Biringkanaya Subdistrict with an area of $209,090.08 \mathrm{~m} 2$, Tamalanrea Sub-district with an area of $98,183.47 \mathrm{~m} 2$, Tallo Sub-district with an area of 721,530.53 
m2, District of Ujung Tanah with an area of 59,053, $95 \mathrm{~m} 2$, Wajo District covering 10,213.8 m2, Ujung Pandang District covering 26,492.2 m2, Tamalate District covering 1,369,692.6 $\mathrm{m} 2$ for segment 3 and Tamalate District covering 201,070.21 $\mathrm{m} 2$ in segment 4 . Whereas the reduction in land in $2009-2019$ amounted to $319,044.44 \mathrm{~m} 2$ with the respective widths namely: Biringkanaya District covering 11,580.14 m2, Tamalanrea District covering 105,233.53 m2, Tallo District covering 20,950.48 m2, Ujung Tanah District covering 45,250.39 m2, Wajo District covering an area of 20,034.79 m2, Ujung Pandang District covering an area of 22,615.44 m2, Tamalate District covering an area of 74,836.05 $\mathrm{m} 2$ for segment 3 and Tamalate District covering an area of $18,543.62 \mathrm{~m} 2$ in segment 4.

The coastline changes that occur in the coastal area of Makassar City are the same as the results of a study conducted by Yulius and Ramdhan (2013) about changes in the coastline in the Bungus Bay of Padang City, which occur accretion and experience abrasion on the other side and the methods used in his research of landsat 5TM images in 2000, Ikonos in 2006, ALOS in 2010 and Spot in 2011.

The factors that cause changes in the coastline in the coastal area of Makassar City are caused by hydro-oceanographic factors (natural factors) and are caused by human activities. Natural factors can cause changes in coastline in the form of abrasion or accretion. Such as high waves, current velocity, sediment transport and tides. While anthropogenic factors (human activities) carried out in the coastal area of Makassar City in the form of the construction of the port of the pier / port (Biringkanaya District, Tallo, Ujung Tanah and Tamalate). The accretion was caused by the reclamation namely the process of making new land from the seabed, which will be used as a place to build buildings and serve as a tourist area,carried out by the local government in the form of the Center Point of Indonesia (CPI) project in Tamalate District segment 3. The existence of residential land use for the community, as tourist attractions in Tamalate and Tamalanrea Districts. This is supported by the results of Shuhendry's research (2004) which states that the cause of damage / changes in coastline caused by human activities (anthropogenic) including the taking or transfer of coastal protective land functions and development in coastal areas that are not in accordance with applicable rules and cause imbalances sediment transport along the coast.

\section{Discussion}

Changes in the coastline occur because, firstly due to the use of land where people build buildings on the beach, especially in the District of Tamalanrea (Segment 2), secondly caused by the cutting down of mangrove trees so that it causes abrasion on the shoreline, thirdly caused by natural factors namely currents and waves, although the effect is not too large but occur continuously. Finally, the fourth cause is the existence of reclamation such as the construction of a wharf for fishermen in Biringkanaya District, Ujung Tanah District and Tamalate District. Furthermore, the construction of the CPI (Indonesian point) in Tamalate Sub-district is to be used as a tourist area

\section{Conclusion}

Based on the results and discussion in this study, it can be concluded that:

1. Coastal changes that occur in the coastal area of Makassar
City based on comparison of Landsat 7 ETM + 2009 image data with Landsat 8 OLI image data in 2019 there was a change in coastline in the form of abrasion and accretion.

2. Changes in the coastline that occurred in the coastal area of Makassar City over a period of 10 years in the form of accretion of 2,695,326.84 m2 and abrasion of 319,044.44 $\mathrm{m} 2$.

3. The coastline of Makassar City in 2009 was $37.79 \mathrm{~km}$. Whereas in 2019 there was a significant change, namely $49.82 \mathrm{~km}$. this shows the addition of a coastline of 12.03 $\mathrm{km}$.

\section{Acknowledgment}

We sincerely thank all parties who have helped in research and data analysis.

\section{References}

Agus, I Made, Wirahadi Putra, Adhi Susanto, And Indah Soesanti. 2015. "Ekstraksi Garis Pantai Pada Citra Satelit Landsat Dengan Metode Segmentasi Dan Deteksi Tepi." Jurnal Nasional Pendidikan Teknik Informatika (Janapati) 4(3): 115-20.

Angkotasan, Abdul Motalib, I Wayan Nurjaya, And Nyoman M N Natih. 2012. "Analisis Perubahan Garis Pantai Di Pantai Barat Daya Pulau Ternate, Provinsi Maluku Utara ( Shoreline Change Analysis Of The South West Coast At Ternate Island , North Molucas Province ).” Jurnal Teknologi Perikanan Dan Kelautan 3(2): 11-22.

Aryastana, Putu, I Gusti Agung Putu Eryani, And Kadek Windy Candrayana. 2015. "Perubahan Garis Pantai Dengan Citra Satelit Di Kabupaten Gianyar.” Paduraksa 5(2): 70-81.Fan, Yaoshen Et Al. 2017. "Shoreline Dynamics Of The Active Yellow River Delta Since The Implementation Of Water-Sediment Regulation Scheme: A Remote-Sensing And Statistics-Based Approach." Www.Elsevier.Com/Open-Access.

Kulmawapa. A. R., Afu. A. O. L., Takwir. A. 2017. Studi Perubahan Garis Pantai Dengan Pendekatan Penginderaan Jauh Di Wilayah Pesisir Kecamatan Mawasangka Kabupaten Buton Tengah. Diakses Pada Tanggal: 17 Juli 2019. [Sumber: Http://Ojs.Uho.Ac.Id/Index.Php/Js1/Article/View/3610]

Suwandana, Endan. 2019. "Depik." Depik, Jurnal Ilmu-Ilmu Perairan, Pesisir Dan Perikanan 8(3): 193-206.

Syukhriani, Silvy, Eko Nofridiansyah, And Bambang Sulistyo. 2017. "Analisis Data Citra Landsat Untuk Pemantauan Perubahan Garis Pantai Kota Bengkulu." Jurnal Enggano 2(1): 90-100.

Wicaksono, Arief, And Pramaditya Wicaksono. 2019. "Akurasi Geometri Garis Pantai Hasil Transformasi Indeks Air Pada Berbagai Penutup Lahan Di Kabupaten Jepara." Majalah Geografi Indonesia 33(1): 86-94.

Tejakusuma I. G. 2011. Pengkajian Kerentanan Fisik Untuk Pengembangan Pesisir Wilayah Kota Makassar. Jurnal Sains Dan Teknologi Indonesia. 13(2) : 82-87.

Yulius M., Dan Ramdhan. 2013. Perubahan Garis Pantai Di Teluk Bungus Kota Padang Provinsi Sumatra Barat Berdasarkan Analisis Citra Satelit. Jurnal Ilmu Dan Teknologi Kelautan Tropis. 5(2) : 417-427.

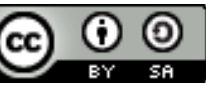

(C) 2020 Journal of Geoscience, Engineering, Environment and Technology. All rights reserved. This is an open access article distributed under the terms of the CC BY-SA License (http://creativecommons.org/licenses/by-sa/4.0/). 